\title{
The Distribution of Sedimentary Organic Matter and Implication of Its Transfer from Changjiang Estuary to Hangzhou Bay, China
}

\author{
Fanglu Xu1 ${ }^{1}$ Zhongqiang Ji², Kui Wang2, Haiyan Jin², Pei Sun Loh ${ }^{*}$ \\ ${ }^{1}$ Institute of Marine Chemistry and Environment, Department of Marine Sciences, Ocean College, Zhejiang \\ University, Zhoushan, China \\ ${ }^{2}$ Laboratory of Marine Ecosystem and Biogeochemistry, SOA, Second Institute of Oceanography, the State \\ Oceanic Administration, Hangzhou, China \\ Email: *psloh@zju.edu.cn
}

Received 15 December 2015; accepted 26 January 2016; published 29 January 2016

Copyright (C) 2016 by authors and Scientific Research Publishing Inc.

This work is licensed under the Creative Commons Attribution International License (CC BY).

http://creativecommons.org/licenses/by/4.0/

(c) (i)

\section{Abstract}

In this study, a comparison was made between the Changjiang Estuary and the Hanghzou Bay, in terms of the sources and diagenesis of the sedimentary organic matter (OM). To achieve this purpose, surface sediments from the estuary and bay were analyzed for lignin-derived phenols, stable carbon isotope and TOC/TN (total organic carbon/total nitrogen) molar ratio. The signal of landderived OM decreased, and the vanillic acid to vanillin ratio, (Ad/Al)v, increased with increasing distance from the Changjiang Estuary and the Hangzhou Bay. These results corresponded with the contribution of the terrigenous $O M$ from the rivers to the coastal zone, and the predominance of marine $\mathrm{OM}$ farther offshore, and that the land-derived $\mathrm{OM}$ underwent decomposition during transport along the estuary and bay. It should be noted that besides the Qiantang River, Hangzhou Bay is also receiving more than half of its materials from Changjiang Estuary, which flows into the Hangzhou Bay at the north, and leaves via the southern part of the bay. This important aspect of the hydrological cycle in Hangzhou Bay corresponded to higher $\Lambda$ (total lignin in $\mathrm{mg} / \mathbf{1 0 0} \mathrm{mg} \mathrm{OC}$ ), higher TOC and $\mathrm{C} / \mathrm{N}$ ratios and more elevated (Ad/Al)v and (Ad/Al)s values in the bay than the Changjiang Estuary, thus, rendering the bay as a site for the accumulation and rapid cycling of terrigenous $\mathrm{OM}$.

\section{Keywords}

Changjiang Estuary, Hangzhou Bay, Sedimentary Organic Matter, Lignin

\footnotetext{
${ }^{*}$ Corresponding author.
}

How to cite this paper: Xu, F.L., Ji, Z.Q., Wang, K., Jin, H.Y. and Loh, P.S. (2016) The Distribution of Sedimentary Organic Matter and Implication of Its Transfer from Changjiang Estuary to Hangzhou Bay, China. Open Journal of Marine Science, 6, 103-114. http://dx.doi.org/10.4236/ojms.2016.61010 


\section{Introduction}

Estuaries are zones of connection between land and ocean, which are vulnerable to the effects of global climate change. For instance, the warming of water has resulted in the changing of the timing and magnitude of phytoplankton bloom in estuaries [1], extreme weather condition, such as cyclone event has caused flash flood, which in turn, increased the contribution of river discharge into the adjacent estuary [2], and the sea level rise due to the effect of global warming on the hydrological cycle of estuaries, causing an increased intrusion of sea water farther upstream [3]. Based on these reasons, some measures have been put in place to assess the vulnerability of the coastal zone, so that proper management in terms of sedimentation, land subsidence, land rehabilitation and reclamation can be carried out [4].

The Changjiang Estuary is a funnel-shaped estuary, which is drained by the Changjiang River, the largest river in China, whereas, the Hangzhou Bay is a funnel-shaped bay drained by the Qiantang River ([5]; references therein]. Hangzhou Bay, situated at the immediate south of the Changjiang Estuary, is one of the largest macro-tidal estuaries in the world. It has an area of about $4800 \mathrm{~km}^{2}$, and is surrounded by one of the most urbanized areas in China. The bay is shallow, being about $100 \mathrm{~km}$ long and it is about $100 \mathrm{~km}$ and $25 \mathrm{~km}$ wide at the mouth and upstream, respectively. Changjiang River contributes approximately $925 \times 10^{9} \mathrm{~m}^{3} / \mathrm{yr}$ of water and $486 \times 10^{6} \mathrm{t} / \mathrm{yr}$ of sediment into the Changjiang Estuary [6]. Qiantang and Cao-E Rivers are the main and second-most important rivers discharging into the Hangzhou Bay, and both rivers contribute approximately 448 $\times 10^{8} \mathrm{~m}^{3} / \mathrm{yr}$ and $786 \times 10^{4} \mathrm{t} / \mathrm{yr}$ of water and sediment, respectively, into the Hangzhou Bay ([6]; references therein). Since the construction of the Three Gorges Dam at the upstream of the Changjiang River, the annual sediment load has been reduced from, approximately, $4.18 \times 10^{8}$ tons to less than $2 \times 10^{8}$ tons [7]. This reduced amount of sediment load is still large compared to the total discharge by both Qiantang and Cao-E Rivers put together. Hence, previous estimate showed that most of the sediments in the Hangzhou Bay are inputs from the Changjiang River, via the Changjiang River Diluted Water (CDW) current, and only a minor source, which is less than 2 percent of the amount of the Changjiang sediment input, and coming from the Qiantang River [8] could still be applicable, but most probably with an increase in the ratio of contribution from the Qiantang River. Consequently, Changjiang River has an important influence on the Hangzhou Bay sedimentary sources and therefore, should be studied together [5]. Because of its importance as a sediment passage and trap between the Changjiang and Qiantang Rivers, Hangzhou Bay could be vulnerable to the changes in sediment load from the Changjiang River [9].

Extensive studies have been carried out to determine the impacts of the Three Gorges Dam as well as the human activities on the physical and chemical properties of the Changjiang Estuary and its adjacent shelf. Building of dams have led to some changes in the Changjiang Estuary, for example, the distribution of coarse and fine grained sediments along the estuary [10], a retreat of the turbidity maximum zone, northward of the river plume [11] and a decrease in sediment input into the estuary [12]. Human activities, such as agriculture and livestock farming [13] have resulted in increased nutrient input [14]-[16] and subsequently, lead to algae bloom [13] [17] and hypoxia in this region [18]. Studies of sediment organic geochemistry have also been carried out along the Changjiang Estuary and its adjacent shelf, in terms of historical profile, based on sediment cores, which showed increased human influences in recent years [14] [18] [19], as well as along a transect of the estuary and its adjacent shelf [20]-[22]. Less number of such studies has been carried out in the Hangzhou Bay. In this study, we investigated the sources, distribution and fate of sedimentary organic matter (OM) along the Changjiang Estuary, and the Hangzhou Bay, with the aim that a comparison between the estuary and bay would give us better insights into the dynamics of the terrigenous OM in the Hangzhou Bay.

\section{Methodology}

\subsection{Sediment Sampling}

Samplings were carried out during the months of October and November, in the year 2007, on board a fishing vessel. One replicate of sediments was collected from the surface, to approximately $5-10 \mathrm{~cm}$ deep, using a stainless steel box corer from each location, along the Changjiang Estuary and the Hangzhou Bay. Sediments were stored frozen upon sampling, freeze-dried and homogenized using a mortar and pestle. Locations and sampling information are given in Table 1 and shown in Figure 1. 
Table 1. Sampling locations and bulk elemental and $\delta^{13} \mathrm{C}$ results.

\begin{tabular}{cccccccccc}
\hline No. & Location & $\begin{array}{c}\text { Sampling } \\
\text { time }\end{array}$ & $\begin{array}{c}\text { Longitude } \\
\left({ }^{\circ} \mathrm{E}\right)\end{array}$ & $\begin{array}{c}\text { Latitude } \\
\left({ }^{\circ} \mathrm{N}\right)\end{array}$ & $\begin{array}{c}\text { Water depth } \\
(\mathrm{m})\end{array}$ & $\begin{array}{c}\delta^{13} \mathrm{C} \\
(\%)\end{array}$ & $\begin{array}{c}\text { TOC } \\
(\%)\end{array}$ & $\begin{array}{c}\mathrm{TN} \\
(\%)\end{array}$ & $\begin{array}{c}\text { C/N molar } \\
\text { ratio }\end{array}$ \\
\hline 1 & M5-10 & $2007 / 10 / 13$ & 121.8 & 31.2 & 11 & -23.4 & 0.98 & 0.092 & 12.4 \\
2 & M4-1 & $2007 / 10 / 11$ & 122.1 & 31.0 & 6 & -24.3 & 0.89 & 0.083 & 12.5 \\
3 & M4-2 & $2007 / 11 / 09$ & 122.2 & 31.0 & 11 & -22.9 & 0.60 & 0.10 & 7.0 \\
4 & N5-4 & $2007 / 10 / 31$ & 121.5 & 30.5 & 12 & -23.4 & 0.84 & 0.054 & 18.1 \\
5 & N4-8 & $2007 / 10 / 31$ & 121.8 & 31.2 & 11 & -23.4 & 0.98 & 0.092 & 12.4 \\
6 & N11-4 & $2007 / 11 / 02$ & 121.8 & 30.2 & 13 & -23.2 & 0.87 & 0.059 & 17.2 \\
7 & M4-4 & $2007 / 11 / 09$ & 122.6 & 31.0 & 16 & -22.4 & 0.50 & 0.08 & 7.3 \\
8 & M4-6 & $2007 / 11 / 09$ & 122.8 & 31.0 & 26 & -22.2 & 0.63 & 0.11 & 6.7 \\
9 & M2-8 & $2007 / 10 / 24$ & 123.1 & 31.5 & 35 & & 0.17 & 0.019 & 10.4 \\
10 & M4-8 & $2007 / 11 / 19$ & 123.0 & 31.0 & 50 & -20.9 & 0.51 & 0.052 & 11.5 \\
11 & O7-5 & $2007 / 11 / 15$ & 122.9 & 30.7 & 41 & -21.9 & 0.50 & 0.10 & 5.8 \\
12 & O5-5 & $2007 / 11 / 12$ & 122.9 & 30.0 & 50 & -21.9 & 0.92 & 0.07 & 15.3 \\
13 & O6-5 & $2007 / 11 / 12$ & 123.1 & 30.0 & 50 & -22.4 & & &
\end{tabular}

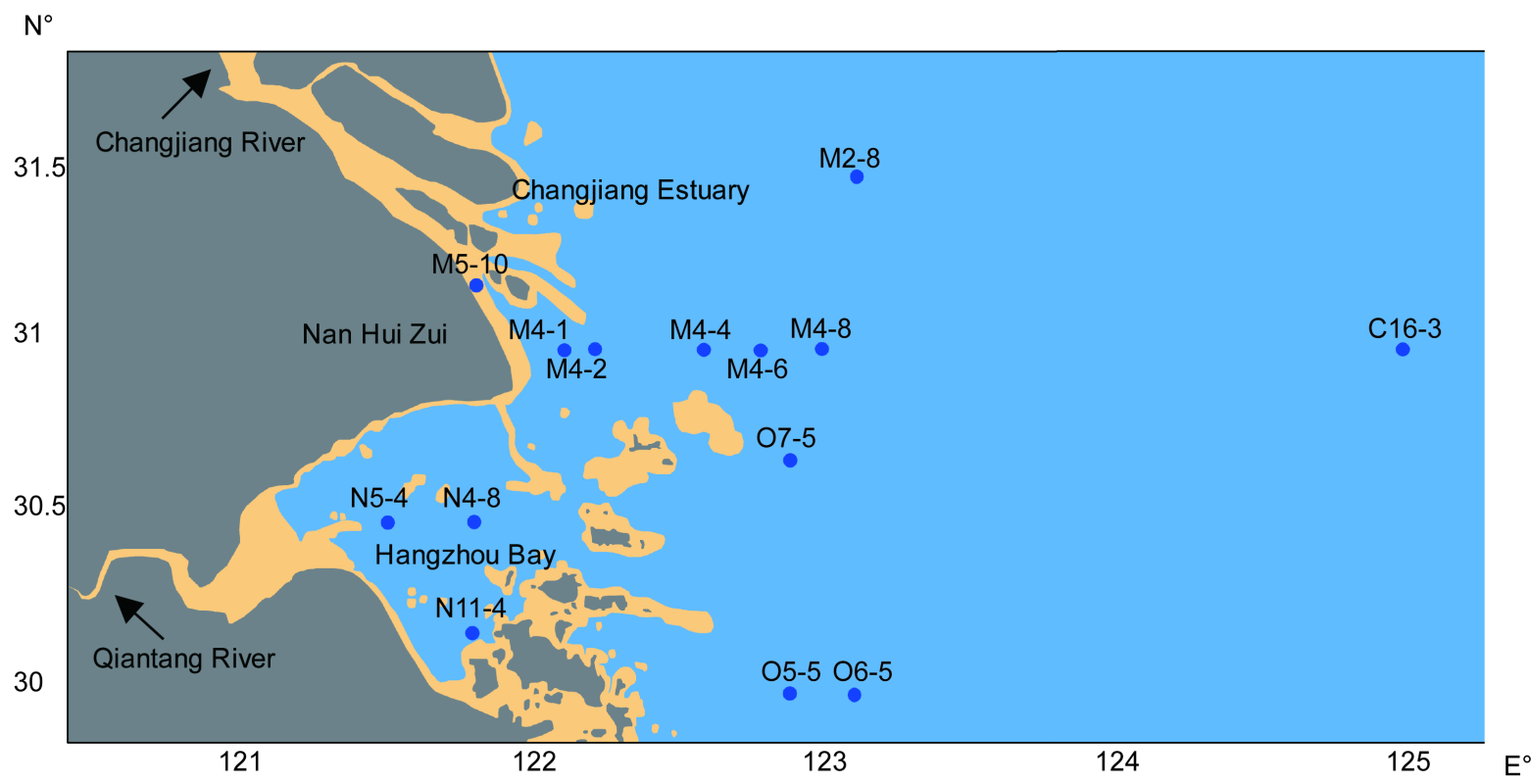

Figure 1. Map of study area.

\subsection{Analyticall Method}

Lignin analysis was based on the method of Hedges \& Ertel (1982) [23], and the references therein. Briefly, dry sediment and $\mathrm{CuO}$ powder were weighed into a polytetrafluoroethylene (PTFE) vessel, and $2 \mathrm{M}$ aqueous $\mathrm{NaOH}$ was bubbled with $\mathrm{N}_{2}$. These were purged with $\mathrm{N}_{2}$ for a few minutes, the $\mathrm{NaOH}$ solution was then added into the contents of the PTFE vessel and the vessel was capped. The vessels were heated at room temperature to $170^{\circ} \mathrm{C}$ for 3 hours, and manually shaken every hour. After completion of the heating process, the vessels were cooled. After that, the contents were washed three times with $1 \mathrm{M} \mathrm{NaOH}$, centrifuged, and all supernatants were com- 
bined and acidified to $\mathrm{pH} 1$ with $6 \mathrm{M} \mathrm{HCl}$. These were extracted three times with $20 \mathrm{~mL}$ ethyl acetate, spiked with ethylvanillin as the internal standard, the extracts were dried with anhydrous $\mathrm{Na}_{2} \mathrm{SO}_{4}$, filtered through a filter paper and concentrated to $1-2 \mathrm{~mL}$. The solid oxidation product was dissolved in an equal amount of pyridine and bis (trimethylsilyl) trifluoroacetamide, with $10 \%$ trimethylchlorosilane (TMCS), derivatized at $90^{\circ} \mathrm{C}$ for 10 minutes and ready to be analyzed by gas chromatography (GC) HP5890A with a flame ionization detection, using a $30 \mathrm{~m} \times 0.25 \mathrm{~mm}$ i.d. HP1 capillary column. The GC column temperature increased from $100^{\circ} \mathrm{C}$ to $300^{\circ} \mathrm{C}$ at $4^{\circ} \mathrm{C} / \mathrm{min}$.

For bulk elemental analysis, the dried sediment was added with $1 \mathrm{M} \mathrm{HCl}$ to remove the inorganic carbon. The residues were then dried and ground to homogenize. A precise amount of sediment was weighed into a tin foil and crimped into a pellet. Total organic carbon (TOC) was determined using an Elementar Analyzer (vario ISOTOPE cube). Sulphanilamide was used as the standard reference material and precision was $0.02 \%$ for organic carbon (OC) and $0.005 \%$ for total nitrogen $(\mathrm{TN}) . \delta^{13} \mathrm{C}$ values were obtained using the Isotope ratio mass spectrometer (Thermo, MAT 253). PDB (Pee Dee Belemnite) was used as the standard reference material and the precision was $0.2 \%$.

\section{Results}

\section{1. $\delta^{13} \mathrm{C}$, TOC and C/N Molar Ratios}

The stable carbon isotope and bulk elemental results of TOC, TN and TOC/TN molar ratios (henceforth, known as $\mathrm{C} / \mathrm{N}$ ratio) are presented in Table $1 . \delta^{13} \mathrm{C}$ values and $\mathrm{C} / \mathrm{N}$ ratio are used as indicators of the sources of sedimentary OM, because vascular land plants have, comparatively, more depleted $\delta^{13} \mathrm{C}$ values ( $-22 \%$ o to $-35 \%$ ) than phytoplankton materials $(-12 \%$ o to $-23 \%)$; and plant-derived $\mathrm{OM}$ have higher $\mathrm{C} / \mathrm{N}$ ratios $(>23.3)$ than phytoplankton materials (4.7 to 11.7; [24]). The $\delta^{13} \mathrm{C}$ values in the Changjiang Estuary and the Hangzhou Bay, ranged from -20.94\%o at N4-8 (the easternmost location in Changjiang Estuary) to -24.35\%o at N4-1 (which is near the Changjiang River mouth and near the tip of Nan Hui Zui). Overall, locations near the Changjiang River mouth have more negative $\delta^{13} \mathrm{C}$ values, and the $\delta^{13} \mathrm{C}$ values increased with distance farther offshore, towards the east and south. Similarly, the three locations in the Hangzhou Bay have more negative $\delta^{13} \mathrm{C}$ values $(-23.21$ to $-23.56 \%$ ) than the location at the east and outside Hangzhou Bay, O7-5 (-21.87\%), and the location immediately outside and southeast of Hangzhou Bay, O5-5 (-21.92\%; Figure 2(a)).

The highest TOC\% values were found in the locations near the Changjiang River mouth and estuary, as well as the three locations in Hangzhou Bay. The location right outside and southeast of the Hangzhou Bay, O5-5, also has high TOC\%, which could be attributed to the accumulation of materials from both the Changjiang Estuary and the Hangzhou Bay. All the locations farther offshore showed lower values of TOC\% (Figure 2(b)). $\mathrm{C} / \mathrm{N}$ ratios ranged from 5.8 at O7-5 to 18.1 at the location nearest to the Qiantang River mouth in Hangzhou Bay. Overall, $\mathrm{C} / \mathrm{N}$ ratios showed stronger terrigenous $\mathrm{OM}$ signal around the coastal zone and stronger marine signal farther offshore. Similarly, locations in Hangzhou Bay have higher C/N ratios (ranging from 12.4 to 18.1) than the location towards the east and outside of the bay $(\mathrm{O} 7-5 ; \mathrm{C} / \mathrm{N}=5.8)$, and the location outside and southeast of the bay (O5-5; $\mathrm{C} / \mathrm{N}=15.3)$. Overall, the $\mathrm{C} / \mathrm{N}$ ratios in our study areas showed a similar trend as indicated by the $\delta^{13} \mathrm{C}$ values: high $\mathrm{C} / \mathrm{N}$ ratios indicative of the terrigenous signal, near the Changjiang River mouth and estuary, in comparison with the lower $\mathrm{C} / \mathrm{N}$ ratios or higher marine OM signal which is farther offshore (Figure 2(c)).

\subsection{Lignin Parameters}

Detailed result of lignin parameters is given in Table 2. $\Lambda$ values (total lignin in mg/100 mg OC) ranged from the highest value of 1.07 in Hangzhou Bay to the lowest value of 0.33 at the eastern-most location in this study, which is O16-3 at the East China Sea. Overall, $\Lambda$ values were higher in the locations near the river mouths and estuary, and the values decreased farther towards the sea. $\Lambda$ values in Hangzhou Bay were the highest, compared to locations surrounding the Changjiang River mouth and estuary; $\Lambda$ values in Hangzhou Bay were also higher than the locations at the east and outside the bay. The $\Lambda$ values have similar trends as the $\delta^{13} \mathrm{C}$ values, $\mathrm{C} / \mathrm{N}$ ratios, as well as TOC, thus, indicating the importance of the contribution of terrigenous OM near the coastal zone, which decreased with distance farther away from the river mouths (Figure 3(a)).

Lignin parameters are used as indicators of vegetation sources because angiosperm plants produce vanillyl (V) and syringyl (S) phenols, and gymnosperm plants yield only vanillyl phenols, hence, $\mathrm{S} / \mathrm{V}$ ratios $>0$ are indicative 


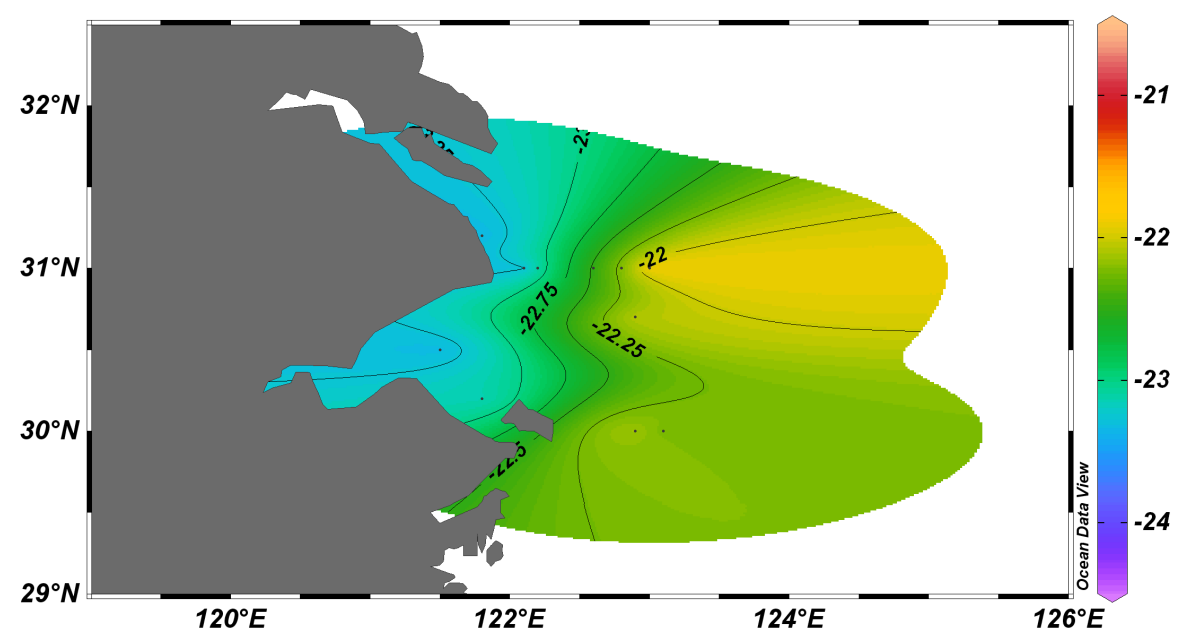

(a)

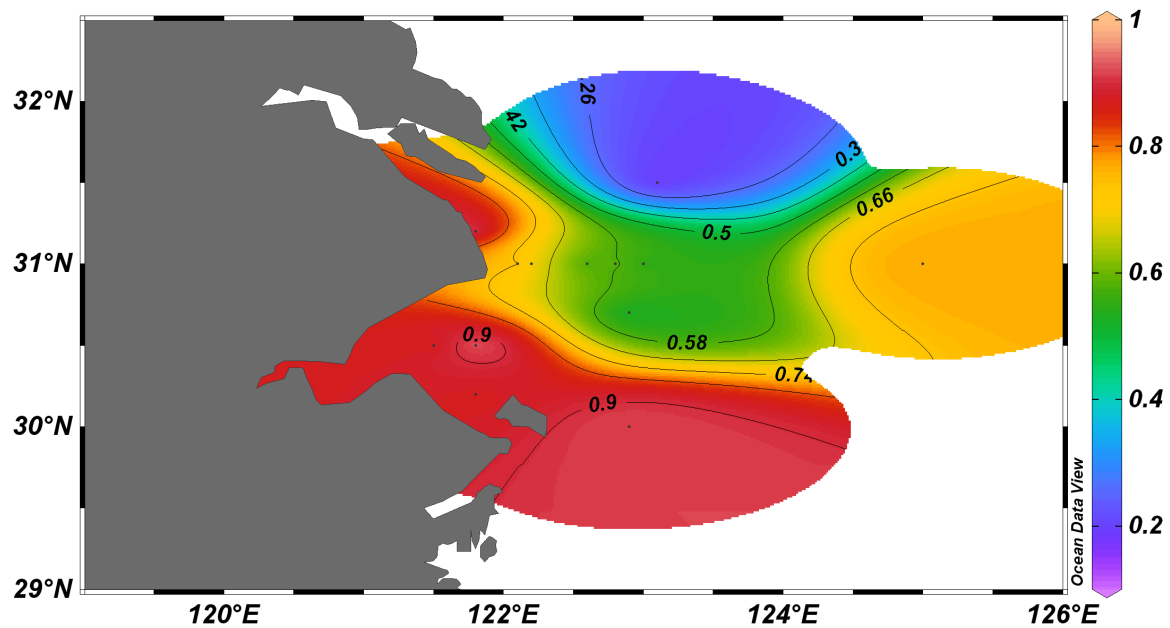

(b)

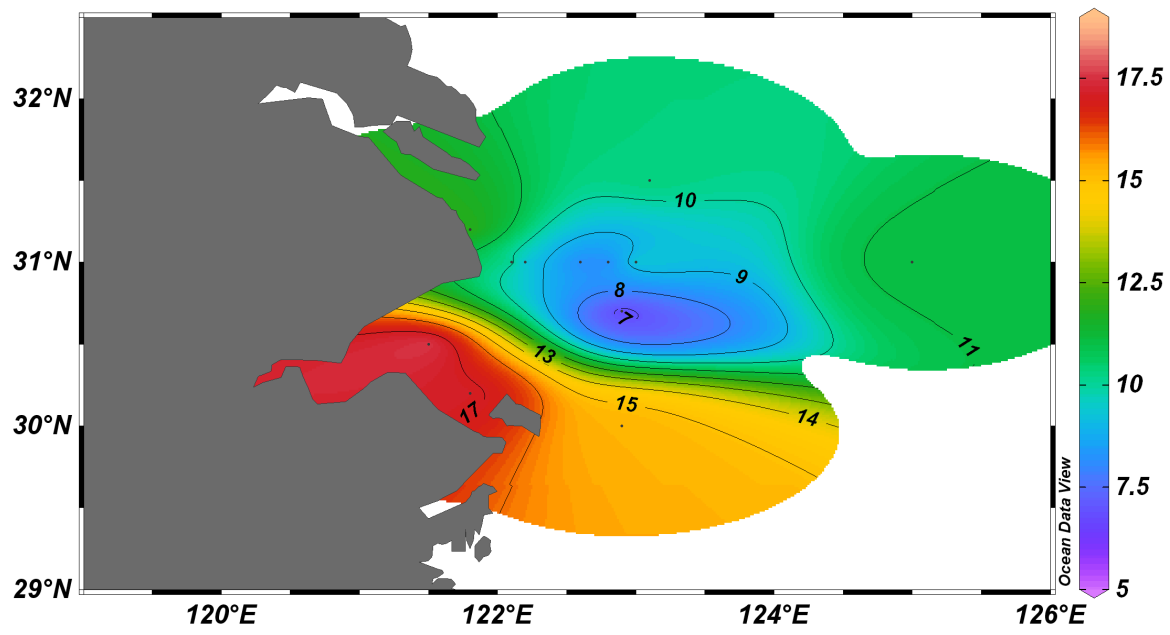

(c)

Figure 2. Spatial distribution of (a) $\delta^{13} \mathrm{C} \%$, (b) TOC\% and (c) $\mathrm{C} / \mathrm{N}$ ratio in surface sediments from Changjiang Estuary, inner ECS shelf and Hangzhou Bay. The areas in the north and south of the map should be interpreted with cautious (especially TOC) as there were few locations sampled here. 
of angiosperm tissues and $\mathrm{S} / \mathrm{V}=0$ represents gymnosperm tissues; and only non-woody vascular plants produce cinnamyl phenols (C), hence, $\mathrm{C} / \mathrm{V}$ ratios $>0$ indicate the presence of non-woody tissues, and $\mathrm{C} / \mathrm{V}=0$ represents woody tissues [25] [26]. The $\mathrm{S} / \mathrm{V}$ ratios in this study area ranged from 0.50 to 1.47 , indicating the presence of angiosperm tissues. The $\mathrm{C} / \mathrm{V}$ ratios ranged from 0.05 to 0.97 , indicating the presence of non-woody and woody tissues. Overall, there was no distinctive trend in the S/V and C/V ratios distribution pattern, indicating a mixture of non-woody and woody angiosperms in this area (Figure 3(b), Figure 3(c)). The ratios of vanillic acid to vanillin, $(\mathrm{Ad} / \mathrm{Al}) \mathrm{v}$, and syringic acid to syringaldehyde, $(\mathrm{Ad} / \mathrm{Al}) \mathrm{s}$, are used as indicators of the lignin decomposition stage, as the ratios of $(\mathrm{Ad} / \mathrm{Al}) \mathrm{v}$ and $(\mathrm{Ad} / \mathrm{Al})$ s for fresh plant materials, range from 0.10 to 0.20 and the ratios increase with a higher decomposition stage of the lignin materials [25]. The ( $\mathrm{Ad} / \mathrm{Al}) \mathrm{v}$ and $(\mathrm{Ad} / \mathrm{Al}) \mathrm{s}$ values showed increase in this order: from the Changjiang River mouth and estuary to the Hangzhou Bay, followed by the highest values at the different locations in the East China Sea and outside of the bay (Figure 3(d), Figure $3(\mathrm{e}))$.

Syringyl phenols (S) is the sum of syringaldehyde, acetosyringone and syringic acid; vanillyl phenols (V) is the sum of vanillin, acetovanillone and vanillic acid; cinnamyl phenols (C) is the sum of cinnamic acid and ferulic acid; TOTAL is the total lignin or sum of $\mathrm{S}, \mathrm{V}$ and $\mathrm{C}$ reported in $\mathrm{mg} / \mathrm{g}$ sediment and $\Lambda$ is the total lignin reported in $\mathrm{mg} / 100 \mathrm{mg}$ OC. Most of the analyses were carried out as one replicate. For those triplicate analyses were carried out, results are reported as mean \pm standard deviation.

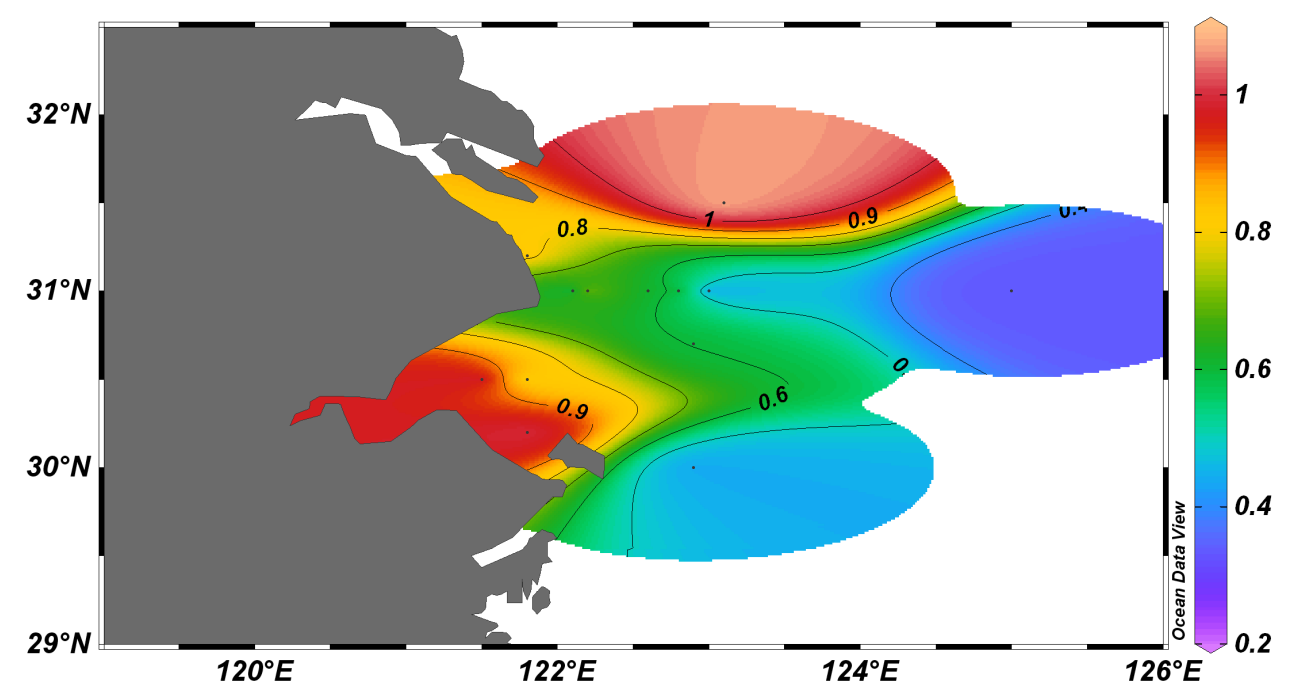

(a)

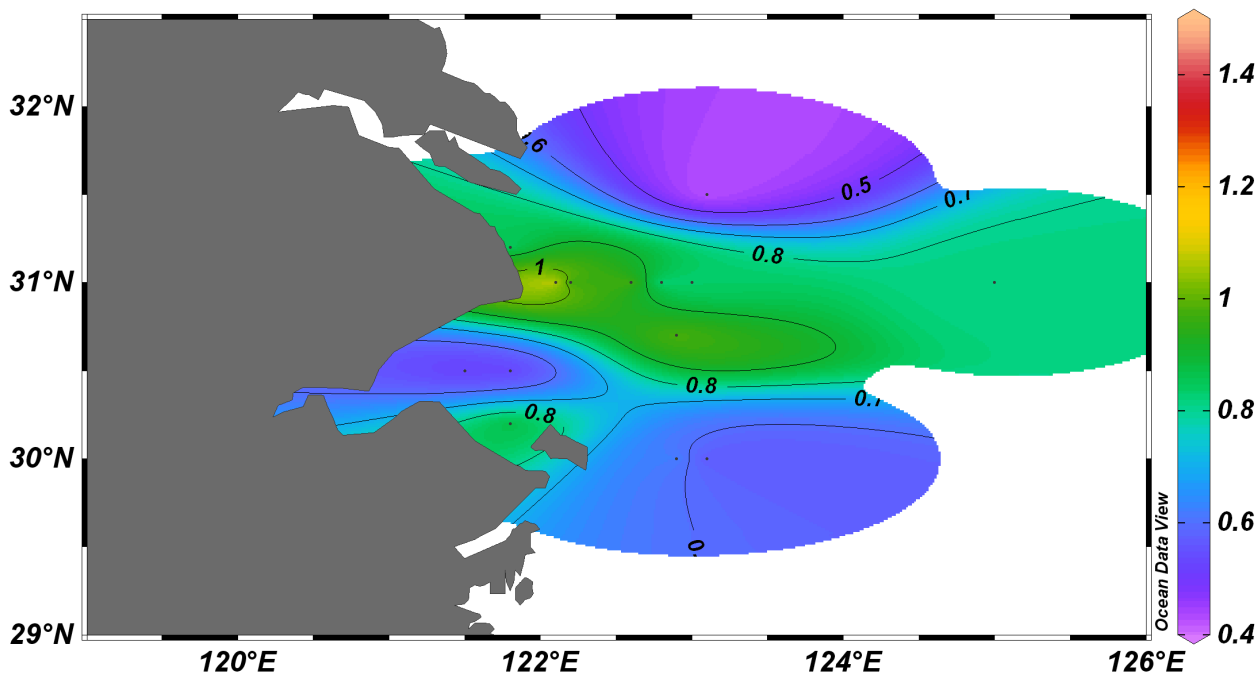

(b) 


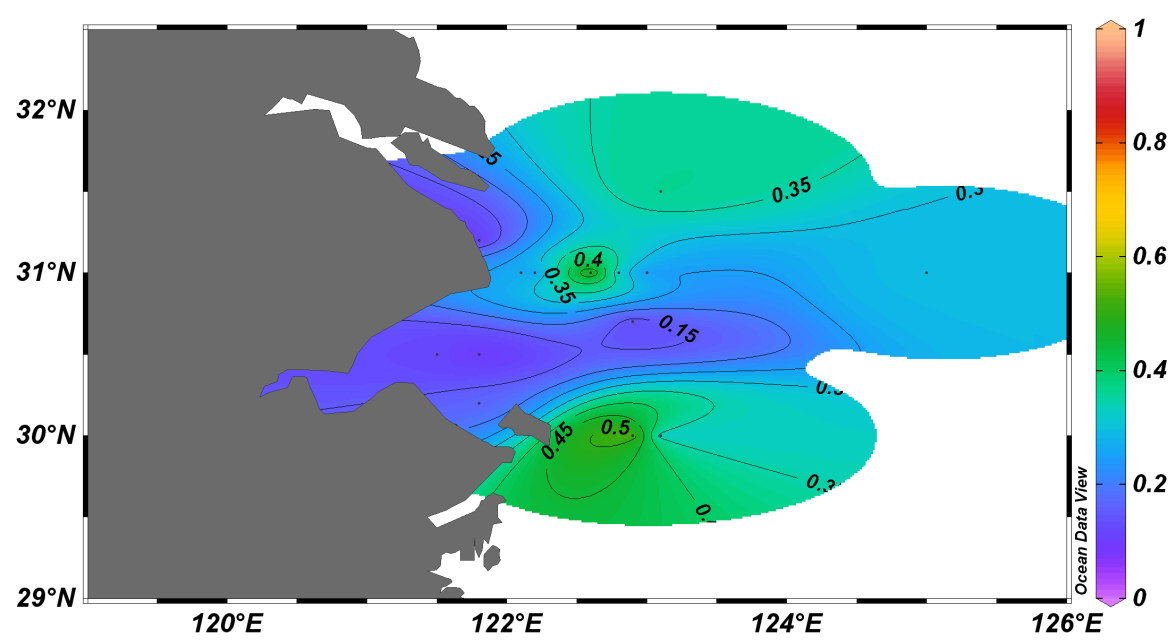

(c)

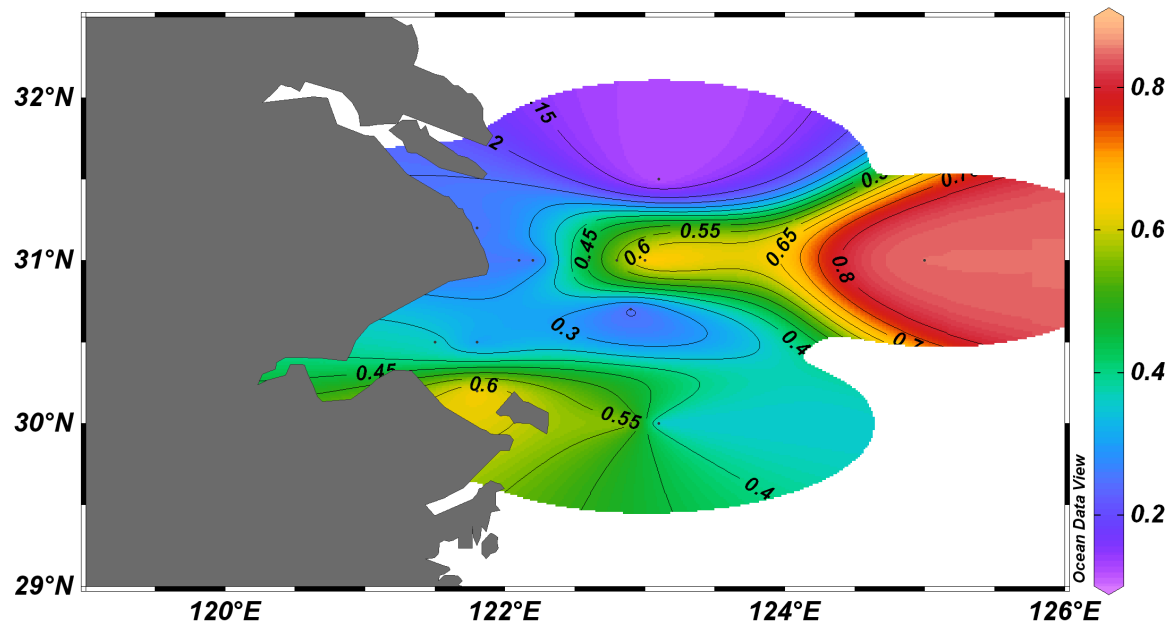

(d)

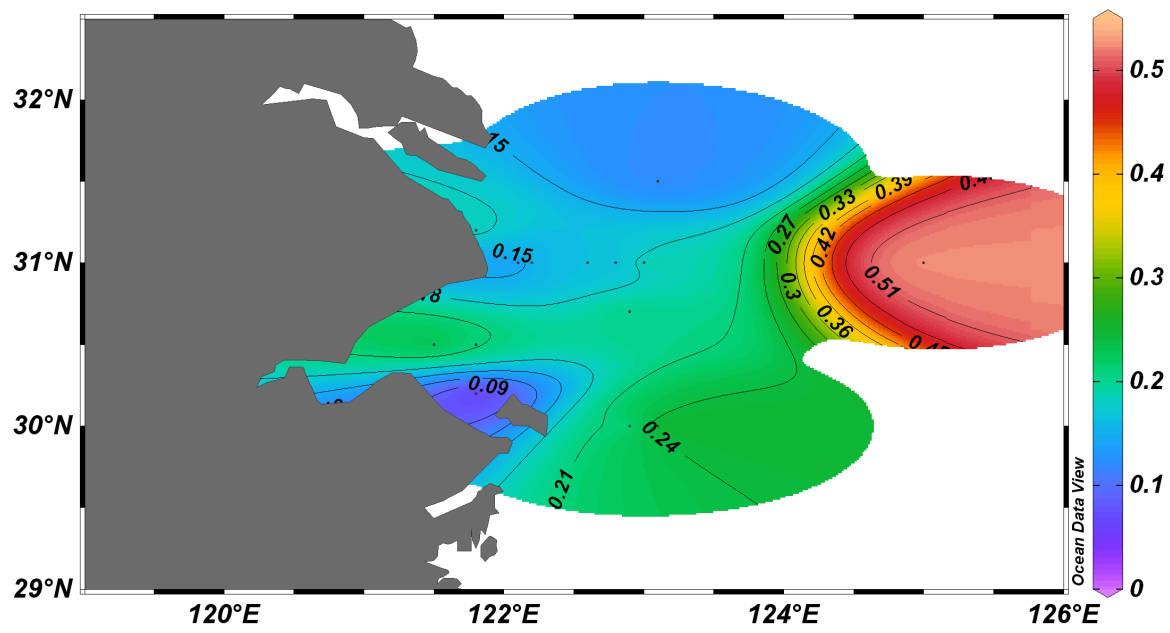

(e)

Figure 3. Spatial distribution of (a) $\Lambda$ (mg/100 mg OC), (b) S/V, (c) C/V, (d) (Ad/Al)v and (e) (Ad/Al)s in surface sediments from Changjiang Estuary, inner ECS shelf and Hangzhou Bay. The areas in the north and south of the map should be interpreted with cautious as there were few locations sampled here. 
Table 2. Lignin parameters for surface sediments along Changjiang Estuary and Hangzhou Bay.

\begin{tabular}{|c|c|c|c|c|c|c|c|c|c|c|}
\hline No. & Station & $\mathrm{S}$ & V & $\mathrm{C}$ & TOTAL & $\Lambda \quad(\mathrm{mg} / 100 \mathrm{mg}$ OC $)$ & $\mathrm{S} / \mathrm{V}$ & $\mathrm{C} / \mathrm{V}$ & $(\mathrm{Ad} / \mathrm{Al}) \mathrm{v}$ & (Ad/Al)s \\
\hline 1 & M5-10 & 0.0367 & 0.0462 & 0.0022 & 0.0851 & 0.8684 & 0.7942 & 0.0466 & 0.2422 & 0.1984 \\
\hline 2 & M4-1 & 0.0171 & 0.0116 & 0.0038 & 0.0325 & 0.3652 & 1.4683 & 0.3239 & 0.2667 & 0.0685 \\
\hline 3 & M4-2 & 0.0211 & 0.0328 & 0.0029 & 0.0568 & 0.9467 & 0.6432 & 0.0868 & 0.1066 & 0.2120 \\
\hline 4 & N5-4 & 0.0277 & 0.0549 & 0.0076 & 0.0901 & 1.0726 & 0.5052 & 0.1379 & 0.3910 & 0.2459 \\
\hline 5 & N4-8 & 0.0226 & 0.0452 & 0.0034 & 0.0712 & 0.7265 & 0.4988 & 0.0741 & 0.2510 & 0.2116 \\
\hline 6 & N11-4 & $\begin{array}{c}0.0389 \pm \\
0.0052\end{array}$ & $\begin{array}{c}0.0424 \pm \\
0.0058\end{array}$ & $\begin{array}{c}0.0069 \pm \\
0.0009\end{array}$ & $\begin{array}{c}0.0883 \pm \\
0.0107\end{array}$ & 1.0149 & $\begin{array}{c}0.9197 \pm \\
0.0818\end{array}$ & $\begin{array}{c}0.1643 \pm \\
0.0313\end{array}$ & $\begin{array}{c}0.6723 \pm \\
0.0972\end{array}$ & $\begin{array}{c}0.0433 \pm \\
0.0077\end{array}$ \\
\hline 7 & M4-4 & 0.0116 & 0.0096 & 0.0093 & 0.0305 & 0.6100 & 1.2021 & 0.9657 & 0.4607 & 0.1719 \\
\hline 8 & M4-6 & $\begin{array}{c}0.0155 \pm \\
0.0026\end{array}$ & $\begin{array}{c}0.0268 \pm \\
0.0063\end{array}$ & $\begin{array}{c}0.0038 \pm \\
0.0005\end{array}$ & $\begin{array}{c}0.0461 \pm \\
0.0091\end{array}$ & 0.7317 & $\begin{array}{c}0.5891 \pm \\
0.0702\end{array}$ & $\begin{array}{c}0.1453 \pm \\
0.0230\end{array}$ & $\begin{array}{c}0.5710 \pm \\
0.0358\end{array}$ & $\begin{array}{c}0.1293 \pm \\
0.0102\end{array}$ \\
\hline 9 & M2-8 & $\begin{array}{c}0.0043 \pm \\
0.0002\end{array}$ & $\begin{array}{c}0.0104 \pm \\
0.0006\end{array}$ & $\begin{array}{c}0.0038 \pm \\
0.0003\end{array}$ & $\begin{array}{c}0.0185 \pm \\
0.0007\end{array}$ & 1.0882 & $\begin{array}{c}0.4111 \pm \\
0.0367\end{array}$ & $\begin{array}{c}0.3685 \pm \\
0.0183\end{array}$ & $\begin{array}{c}0.1052 \pm \\
0.0138\end{array}$ & $\begin{array}{c}0.1211 \pm \\
0.0270\end{array}$ \\
\hline 10 & M4-8 & $\begin{array}{c}0.0048 \pm \\
0.0008\end{array}$ & $\begin{array}{c}0.0059 \pm \\
0.0011\end{array}$ & $\begin{array}{c}0.0008 \pm \\
0.0001\end{array}$ & $\begin{array}{c}0.0115 \pm \\
0.0002\end{array}$ & 0.2255 & $\begin{array}{c}0.8434 \pm \\
0.2830\end{array}$ & $\begin{array}{c}0.1327 \pm \\
0.0390\end{array}$ & $\begin{array}{c}0.8466 \pm \\
0.0971\end{array}$ & $\begin{array}{c}0.2247 \pm \\
0.0198\end{array}$ \\
\hline 11 & O7-5 & 0.0144 & 0.0143 & 0.0012 & 0.0299 & 0.5980 & 1.0103 & 0.0867 & 0.1761 & 0.2119 \\
\hline 12 & O5-5 & 0.0110 & 0.0164 & 0.0124 & 0.0397 & 0.4315 & 0.6721 & 0.7570 & 0.7991 & 0.1795 \\
\hline 13 & O6-5 & 0.0117 & 0.0229 & 0.0026 & 0.0372 & - & 0.5121 & 0.1116 & 0.1186 & 0.2878 \\
\hline 14 & C16-3 & 0.0099 & 0.0121 & 0.0036 & 0.0256 & 0.3325 & 0.8144 & 0.2939 & 0.8509 & 0.5275 \\
\hline
\end{tabular}

\section{Discussion}

The most significant trend in the Changjiang Estuary is increased $\delta^{13} \mathrm{C}$ values, decreased $\Lambda$, and decreased C/N ratios, from the Changjiang River mouth and estuary, to the locations farther offshore, indicating the importance of the contribution of terrigenous OM from the Changjiang River, and the predominance of marine OM farther offshore. The three locations in Hangzhou Bay also showed more negative $\delta^{13} \mathrm{C}$ values, higher $\Lambda$ values and higher $\mathrm{C} / \mathrm{N}$ ratios than O7-5 (outside, at the east of the bay) and O5-5 (outside, at the southeast of the bay). This trend is in accordance with other studies along the coastal zone [27], mangroves and estuaries [28], sea lochs [29], among others. Our results are also consistent with previous studies in this region, which found higher contribution of vascular plant signal near the coastal zone and the dilution with marine OM farther offshore: such was the case in Changjiang Estuary [20]-[22] [30]-[32] as well as in Hangzhou Bay [32] [33]. Terrigenous OM from the Changjiang River was transported southward along the Zhejiang-Fujian coastline and it decreased further seaward due to the effect of Changjiang River input and currents [31] [34]. As for the Hangzhou Bay, Che et al. (2003) [5], who determined the heavy metal concentrations in the suspended sediments and bed load in the Changjiang Estuary and Hangzhou Bay, found that the abundance of fine-grained sediments and heavy metal concentrations in the suspended sediments were higher in the Changjiang River mouth and decreased with increasing distance from the river mouth. In the Hangzhou Bay, the concentrations of heavy metals were higher in the north than in the southern part, and higher in the east than in the western part. Thus, it was concluded that Changjiang Estuary is of great importance in contributing materials to Hangzhou Bay. The presence of the year-round northeast to southwest front, helps in distributing materials into the bay [5; references therein]. In addition, tidal waves from the East China Sea enter into the Hangzhou Bay at the northwest part of the bay, as the presence of an archipelago in the southwest of the bay hinders the water movement into the bay from the south. Hence, the entire sediments enter the Hangzhou Bay from the north, and leaves through the south in one tidal cycle [6].

With this in mind, that the materials in Hangzhou Bay originated from the Changjiang Estuary and the Qiantang River [8], we presumed that the higher TOC, $\Lambda$ values and $\mathrm{C} / \mathrm{N}$ ratios at the three locations in Hangzhou Bay than the few locations nearest to the Changjiang River mouth indicates an accumulation of OC and terri- 
genous OM in the bay, albeit slightly, but a comparatively higher accumulation than the Changjiang Estuary. Our TOC trends are also consistent with Zhang et al. (2015) [32]. According to Che et al. (2003) [5], input from the Qiantang River mainly discharges into the western and southern parts of the Hangzhou Bay. Contribution from the Qiantang River could have resulted in the higher $\Lambda$ values and $\mathrm{C} / \mathrm{N}$ ratios at the location towards the west (N5-4) and south (N11-4) of the bay, in comparison with the centre of the bay (N4-8). Although the two locations on the west and south of the Hangzhou Bay showed some signal, presumably, due to input from the Qiantang River, no doubt the contribution of materials from the Changjiang estuary was still very much substantial. It is also logical that O7-5 which is situated outside and towards the east of Hangzhou Bay, has lower terrigenous signal than the Changjiang Estuary and the bay, as this location is receiving diluted materials from the Changjiang Estuary. Outside and southeast of Hangzhou Bay is O5-5, which has higher terrigenous signal than O7-5, because O5-5 received input from Hangzhou Bay and from Changjiang Estuary via O7-5.

N11-4 at the south of the bay also showed a higher S/V ratio than the other two locations in the bay, this could indicate the contribution of more angiosperm tissues from the Qiantang River. However, according to the S/V and $\mathrm{C} / \mathrm{V}$ compositional plot (Figure 4), the signal at N11-4 actually represents, more closely, the signal of Changjiang Estuary. The overall non-distinctive pattern of the distribution of $\mathrm{S} / \mathrm{V}$ and $\mathrm{C} / \mathrm{V}$ ratios could be due to the mixing of materials from the Changjiang Estuary. O5-5 has higher C/V ratio of 0.76 than the locations in the bay and towards the north, suggesting that this could be as a result of the hydrodynamic sorting process, whereby, the coarser woody tissues were retained near their places of origin, in comparison with the finer non-woody tissues which were transported farther offshore. For example, the occurrence of the hydrodynamic sorting process has been shown by an increase in the $\mathrm{C} / \mathrm{V}$ ratios from the head to the mouth of the sea lochs, thus, indicating an increase in non-woody tissues at some distance away from the river mouths [29].

A trend of increasing $(\mathrm{Ad} / \mathrm{Al}) \mathrm{v}$ values farther east and south of the Changjiang Estuary was observed, indicating an increased decomposition stage of the lignin materials farther offshore. Our results are consistent with previous studies which found that lignin materials underwent decomposition during transportation, at some distance from the Changjiang River mouth, towards the east and southwards, and that the more degraded lignin materials were normally associated with denser particles farther east and southward [21]. The southern-most location in the Hangzhou Bay, N11-4, have the highest (Ad/Al)v value compared to the other two locations in the bay, and the location adjacent to the Changjiang Estuary. This could indicate the contribution of more degraded

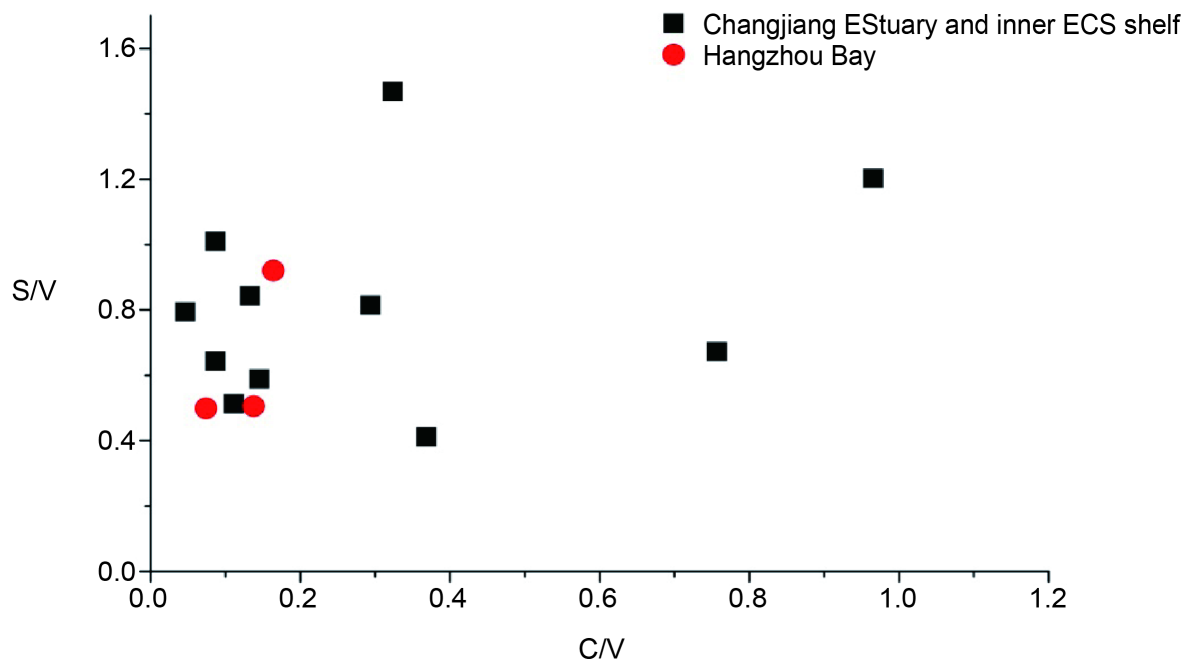

Figure 4. Plot of $\mathrm{S} / \mathrm{V}$ versus $\mathrm{C} / \mathrm{V}$ ratios. $\mathrm{S} / \mathrm{V}$ ratios $>0$ are indicative of angiosperm tissues, $\mathrm{S} / \mathrm{V}=0$ represents gymnosperm tissues, $\mathrm{C} / \mathrm{V}$ ratios $>0$ indicate the presence of non-woody tissues, and $\mathrm{C} / \mathrm{V}=0$ represents woody tissues. Hence, $\mathrm{C} / \mathrm{V}=0$ and very low $\mathrm{S} / \mathrm{V}$ ratios are indicative of a woody gymnosperm signal; a combination of $\mathrm{C} / \mathrm{V}=0$ and slightly higher $\mathrm{S} / \mathrm{V}$ ratios indicating predominance of woody gymnosperms, with a slight contribution from angiosperms; low $\mathrm{S} / \mathrm{V}$ and $\mathrm{C} / \mathrm{V}$ ratios are indicative of woody gymnosperm tissues, with a slight contribution from non-woody tissues; and the highest S/V and $\mathrm{C} / \mathrm{V}$ ratios are indicative of non-woody angiosperms ([25] [35]; references therein). Overall, these results fall within the range of non-woody angiosperm tissues. 
lignin materials from the Qiantang River. Another likely scenario was the increased degradation of lignin materials during transportation, from the Changjiang Estuary into the bay, and from the north of the bay, moving towards the west, and finally, flowing out through the south of the bay. The location outside and southeast of the bay, O5-5, also has higher $(\mathrm{Ad} / \mathrm{Al}) \mathrm{v}$ values than the other locations in its north and in the bay, signifying increased decomposition of lignin materials during transport from the north, and from the bay. Although lignin degradation under sub-aerial conditions is negligible and was normally indicated by the negligible increase in the (Ad/Al)v and (Ad/Al)s values [36] [37]. Lignin decomposition could occur due to the process of photo-oxidation [38] and some studies did find an increased lignin decomposition under sub-aerial conditions [39]. Hangzhou Bay is shallow and has strong tidal current and large tidal range. It is vertically well-mixed, thus, ensuring the mixing of the suspended sediments and surface sediments [5] [6]. Our results showed an increased lignin decomposition along the Hangzhou Bay, most probably due to the strong dynamics and vertically wellmixed condition, replenishing the area with oxygen, thus, facilitating lignin decomposition and resulting in the much elevated $(\mathrm{Ad} / \mathrm{Al}) \mathrm{v}$ and $(\mathrm{Ad} / \mathrm{Al}) \mathrm{s}$ values. Overall, the sediments here were quite recent, as indicated by the mean sedimentation rate in Changjiang Estuary which was higher than $3 \mathrm{~cm} / \mathrm{yr}$ at the delta, and decreased farther offshore towards the east and southwards [40]; and the mean sedimentation rate in Hangzhou Bay was 10 $\mathrm{cm} / \mathrm{yr}$ [6]; hence, the surface sediments collected in this study represents materials of one year old in Hangzhou Bay and materials that are 3 years or older, in the Changjiang Estuary.

\section{Conclusion}

Although the samplings were carried out in 2007, our results along Changjiang Estuary are in accordance with previous comprehensive studies in this region, that is, the importance of contribution of land-derived OM from the Changjiang River and the dilution with marine OM farther offshore. Besides, comparison between the Changjiang Estuary and Hangzhou Bay provides some interesting information. Our results in Hangzhou Bay also showed similar phenomenon. However, comparison between Changjiang Estuary and Hangzhou Bay showed that the bay has a higher $\mathrm{OC}, \mathrm{C} / \mathrm{N}$ ratios and total lignin compared to the estuary. Taking into consideration the unique hydrological cycle in the Hangzhou Bay, these results indicated that the bay accumulated some of the terrigenous input from the Changajing Estuary, and that this terrigenous OM underwent further decomposition in the dynamic bay.

\section{Acknowledgements}

We are thankful to everyone who assisted us during the sampling. This study acknowledges the National Natural Science Foundation of China (No. 41203085), Natural Science Project of Zhejiang Province (No. Y5110171), the Basic Scientific Research Fund of the Second Institute of Oceanography of State Oceanic Administration of China (No. JG1219) and the Zhejiang University Fundamental Research Funds for the Central Universities (2013QNA4037). We are also thankful to the reviewers for their comments which have helped improve the manuscript.

\section{References}

[1] Nixon, S.W., Fulweiler, R.W., Buckley, B.A., et al. (2009) The Impact of Changing Climate on Phenology, Productivity, and Benthic-Pelagic Coupling in Narragansett Bay. Estuarine, Coastal and Shelf Science, 82, 1-18. http://dx.doi.org/10.1016/j.ecss.2008.12.016

[2] Wu, Y., Bao, H.-Y., Unger, D., et al. (2013) Biogeochemical Behavior of Organic Carbon in a Small Tropical River and Estuary, Hainan, China. Continental Shelf Research, 57, 32-43. http://dx.doi.org/10.1016/j.csr.2012.07.017

[3] Chua, V. P. and Xu, M. (2014) Impacts of Sea-Level Rise on Estuarine Circulation: An Idealized Estuary and San Francisco Bay. Journal of Marine Systems, 139, 58-67. http://dx.doi.org/10.1016/j.jmarsys.2014.05.012

[4] Cui, L.F., Ge, Z.M., Yuan, L. and Zhang, L.Q. (2015) Vulnerability Assessment of the Coastal Wetlands in the Yangtze Estuary, China to Sea-Level Rise. Estuarine, Coastal and Shelf Science, 156, 42-51. http://dx.doi.org/10.1016/j.ecss.2014.06.015

[5] Che, Y., He, Q. and Lin, W.-Q. (2003) The Distributions of Particulate Heavy Metals and its Indication to the Transfer of Sediments in the Changjiang Estuary and Hangzhou Bay, China. Marine Pollution Bulletin, 46, 123-131. http://dx.doi.org/10.1016/S0025-326X(02)00355-7

[6] Xie, D.-F., Gao, S., Wang, Z.-B. and Pan, C.-H. (2013) Numerical Modeling of Tidal Currents, Sediment Transport 
and Morphological Evolution in Hangzhou Bay, China. International Journal of Sediment Research, 28, 316-328. http://dx.doi.org/10.1016/S1001-6279(13)60042-6

[7] Dai, Z.J., Chu, A., Stieve, M.J.F. and Li, J.F. (2011) Is the Three Gorges Dam the Cause Behind the Extremely Low Suspended Sediment Discharge into the Yangtze (Changjiang) Estuary of 2006? Hydrological Sciences Journal, 56, 1280-1288. http://dx.doi.org/10.1080/02626667.2011.585136

[8] Chen, J. Y., Liu, C. Z., Zhang, C. L. and Walker, H. J. (1990) Geomorphological Development and Sedimentation in Qiantang Estuary and Hangzhou Bay. Journal of Coastal Research, 6, 559-572.

[9] Wang, X., Shi, X. F., Wang, G.Q., et al. (2015) Late Quaternary Sedimentary Environmental Evolution Offshore of the Hangzhou Bay, East China-Implications for Sea Level Change and Formation of Changjiang Alongshore Current. Chinese Journal of Oceanology and Limnology, 33, 748-763. http://dx.doi.org/10.1007/s00343-015-4172-0

[10] Luo, X.X., Yang, S.L. and Zhang, J. (2012) The Impact of the Three Gorges Dam on the Downstream Distribution and Texture of Sediments Along the Middle and Lower Yangtze River (Changjiang) and its Estuary, and Subsequent Sediment Dispersal in the East China Sea. Geomorphology, 179, 126-140. http://dx.doi.org/10.1016/j.geomorph.2012.05.034

[11] Jiang, X.Z., Lu, B. and He, Y.H. (2013) Response of the Turbidity Maximum Zone to Fluctuations in Sediment Discharge from River to Estuary in the Changjiang Estuary (China). Estuarine, Coastal and Shelf Science, 131, 24-30. http://dx.doi.org/10.1016/j.ecss.2013.07.003

[12] Dai, S.B. and Lu, X.X. (2014) Sediment Load Change in the Yangtze River (Changjiang): A Review. Geomorphology, 215, 60-73. http://dx.doi.org/10.1016/j.geomorph.2013.05.027

[13] Zhao, J., Bianchi, T.S., Li, X.X., Allison, M.A., Yao, P. and Yu, Z.G. (2012) Historical Eutrophication in the Changjiang and Mississippi Delta-Front Estuaries: Stable Sedimentary Chloropigments as Biomarkers. Continental Shelf Research, 47, 133-144. http://dx.doi.org/10.1016/j.csr.2012.07.005

[14] Yu, Y., Song, J.M., Li, X.G. and Duan, L.Q. (2012) Geochemical Records of Decadal Variations in Terrestrial Input and Recent Anthropogenic Eutrophication in the Changjiang Estuary and Its Adjacent Waters. Applied Geochemistry, 27, 1556-1566. http://dx.doi.org/10.1016/j.apgeochem.2012.05.002

[15] Zhu, Z.-Y., Wu, Y., Zhang, J., Du, J.Z. and Zhang, G.-S. (2014) Reconstruction of Anthropogenic Eutrophication in the Region off the Changjiang Estuary and Central Yellow Sea: From Decades to Centuries. Continental Shelf Research, 72, 152-162. http://dx.doi.org/10.1016/j.csr.2013.10.018

[16] Wang, J.N., Yan, W.J., Chen, N.W., Li, X.Y. and Liu, L.S. (2015) Modeled Long-Term Changes of DIN:DIP Ratio in the Changjiang River in Relation to Chl- $\alpha$ and DO Concentrations in Adjacent Estuary. Estuarine, Coastal and Shelf Science, 166, 153-160. http://dx.doi.org/10.1016/j.ecss.2014.11.028

[17] Jiang, Z.B., Liu, J.J., Chen, J.F., Chen, Q.Z., Yan, X.J., Xuan, J.L. and Zeng, J.N. (2014) Responses of Summer Phytoplankton Community to Drastic Environmental Changes in the Changjiang (Yangtze River) Estuary during the Past 50 Years. Water Research, 54, 1-11. http://dx.doi.org/10.1016/j.watres.2014.01.032

[18] Li, X.X., Bianchi, T.S., Yang, Z.S., Osterman, L.E., Allison, M.A., DiMarco, S.F. and Yang, G.P. (2011) Historical Trends of Hypoxia in Changjiang River Estuary: Applications of Chemical Biomarkers and Microfossils. Journal of Marine Systems, 86, 57-68. http://dx.doi.org/10.1016/j.jmarsys.2011.02.003

[19] Li, Z.Q., Wu, Y., Liu, S.M., Du, J.Z. and Zhang, J. (2016) An 800-Year Record of Terrestrial Organic Matter from the East China Sea Shelf Break: Links to Climate Change and Human Activity in the Changjiang Basin. Deep-Sea Research II: Topical Studies in Oceanography, (in Press) http://dx.doi.org/10.1016/j.dsr2.2015.01.006

[20] Yang, L.Y., Wu, Y., Zhang, J., Yu, H., Zhang, G.-S. and Zhu, Z.-Y. (2008) Distribution of Lignin and Sources of Organic Matter in Surface Sediments from the Adjacent Area of the Changjiang Estuary in China. Acta Oceanologica Sinica, 30, 35-42. (In Chinese)

[21] Li, D., Yao, P., Bianchi, T.S., Zhang, T.T., Zhao, B., Pan, H.H., Wang, J.P. and Yu, Z.G. (2014) Organic Carbon Cycling in Sediments of the Changjiang Estuary and Adjacent Shelf: Implication for the Influence of Three Gorges Dam. Journal of Marine Systems, 139, 409-419. http://dx.doi.org/10.1016/j.jmarsys.2014.08.009

[22] Yao, P., Yu, Z.G., Bianchi, T.S., Guo, Z.G., Zhao, M.X., Knappy, C.S., et al. (2015) A Multiproxy Analysis of Sedimentary Organic Carbon in the Changjiang Estuary and Adjacent Shelf. Journal of Geophysical Research: Biogeosciences, 120, 1407-1429. http://dx.doi.org/10.1002/2014jg002831

[23] Hedges, J.I. and Ertel J.R. (1982) Characterization of Lignin by Gas Capillary Chromatography of Cupric Oxide Oxidation Products. Analytical Chemistry, 54, 174-178. http://dx.doi.org/10.1021/ac00239a007

[24] Meyers, P.A. (1994) Preservation of Elemental and Isotopic Source Identification of Sedimentary Organic Matter. Chemical Geology, 114, 289-302. http://dx.doi.org/10.1016/0009-2541(94)90059-0

[25] Hedges, J.I. and Mann, D.C. (1979) The Characterization of Plant Tissues by Their Lignin Oxidation Products. Geo- 
chimica et Cosmochimica Acta, 43, 1803-1807. http://dx.doi.org/10.1016/0016-7037(79)90028-0

[26] Kuzyk, Z.Z.A., Goñi, M.A., Stern, G.A. and Macdonald, R.W. (2008) Sources, Pathways and Sinks of Particulate Organic Matter in Hudson Bay: Evidence from Lignin Distributions. Marine Chemistry, 112, 215-229. http://dx.doi.org/10.1016/j.marchem.2008.08.001

[27] Schmidt, F., Hinrichs, K.-W. and Elvert, M. (2010) Sources, Transport, and Partitioning of Organic Matter at a Highly Dynamic Continental Margin. Marine Chemistry, 118, 37-55. http://dx.doi.org/10.1016/j.marchem.2009.10.003

[28] Prasad, M.B.K. and Ramanathan, A.L. (2009) Organic Matter Characterization in a Tropical Estuarine-Mangrove Ecosystem of India: Preliminary Assessment by Using Stable Isotopes and Lignin Phenols. Estuarine, Coastal and Shelf Science, 84, 617-624. http://dx.doi.org/10.1016/j.ecss.2009.07.029

[29] Loh, P.S., Reeves, A.D., Harvey, S.M., Overnell, J. and Miller, A.E.J. (2008) The Fate of Terrestrial Organic Matter in Two Scottish Sea Lochs. Estuarine, Coastal and Shelf Science, 76, 566-579. http://dx.doi.org/10.1016/j.ecss.2007.07.023

[30] Wu, Y., Dittmar, T., Ludwichowski, K.-W., Kattner, G., Zhang, J., Zhu, Z.Y. and Koch, B.P. (2007) Tracing Suspended Organic Nitrogen from the Yangtze River Catchment into the East China Sea. Marine Chemistry, 107, 367-377. http://dx.doi.org/10.1016/j.marchem.2007.01.022

[31] Xing, L., Zhang, H.L., Yuan, Z.N., Sun, Y. and Zhao, M.X. (2011) Terrestrial and Marine Biomarker Estimates of Organic Matter Sources and Distributions in Surface Sediments from the East China Sea Shelf. Continental Shelf Science, 31, 1106-1115. http://dx.doi.org/10.1016/j.csr.2011.04.003

[32] Zhang, W.Y., Jin, H.Y., Yao, X.Y., Ji, Z.Q., Zhang, X.Y., Yu, X.G., Zhang, F.Y. and Gao, A.G. (2015) Grain Size Composition and Transport of Sedimentary Organic Carbon in the Changjiang River (Yangtze River) Estuary and Hangzhou Bay and Their Adjacent Waters. Acta Oceanologica Sinica, 34, 46-56. http://dx.doi.org/10.1007/s13131-015-0711-y

[33] Chen, P., Pan, D.L., Mao, Z.H. and Tao, B.Y. (2015) Detection of Water Quality Parameters in Hangzhou Bay Using a Portable Laser Fluorometer. Marine Pollution Bulletin, 93, 163-171. http://dx.doi.org/10.1016/j.marpolbul.2015.01.023

[34] Zhu, C., Xue, B., Pan, J.M., Zhang, H.S., Wagner, T. and Pancost, R.D. (2008) The Dispersal of Sedimentary Terrestrial Organic Matter in the East China Sea (ECS) as Revealed by Biomarkers and Hydro-Chemical Characteristics. Organic Geochemistry, 39, 952-957. http://dx.doi.org/10.1016/j.orggeochem.2008.04.024

[35] Bao, H.Y., Wu, Y., Zhang, B., Deng, B. and He, Q. (2014) Composition and Flux of Suspended Organic Matter in the Middle and Lower Reaches of the Changjiang (Yangtze River)-Impact of the Three Gorges Dam and the Role of Tributaries and Channel Erosion. Hydrological Processes, 28, 1137-1147. http://dx.doi.org/10.1002/hyp.9651

[36] Ertel, J.R., Hedges, J.I., Devol, A.H., Richey, J.E. and Ribeiro, M.D.N.G. (1986) Dissolved Humic Substances of the Amazon River System. Limnology and Oceanography, 31, 739-754. http://dx.doi.org/10.4319/10.1986.31.4.0739

[37] Hamilton, S.E. and Hedges, J.I. (1988) The Comparative Geochemistries of Lignins and Carbohydrates in an Anoxic Fjord. Geochimica et Cosmochimica Acta, 52, 129-142. http://dx.doi.org/10.1016/0016-7037(88)90062-2

[38] Bianchi, T.S., Argyrou, M. and Chippett, H.F. (1999) Contribution of Vascular-Plant Carbon to Surface Sediments across the Coastal Margin of Cyprus (Eastern Mediterranean). Organic Geochemistry, 30, 287-297. http://dx.doi.org/10.1016/S0146-6380(99)00016-9

[39] Bianchi, T.S., Wysocki, L.A., Schreiner, K.M., Filley, T.R., Corbett, D.R. and Kolker, A.S. (2011) Sources of Terrestrial Organic Carbon in Mississippi Plume Region: Evidence for the Importance of Coastal Marsh Inputs. Aquatic Geochemistry, 17, 431-456. http://dx.doi.org/10.1007/s10498-010-9110-3

[40] Liu, J.P., Li, A.C., Xu, K.H., Velozzi, D.M., Yang, Z.S., Milliman, J.D. and DeMaster, D.J. (2006) Sedimentary Features of the Yangtze River-Derived Along-Shelf Clinoform Deposit in the East China Sea. Continental Shelf Research, 26, 2141-2156. http://dx.doi.org/10.1016/j.csr.2006.07.013 